\title{
Guerra Assimétrica Reversa ${ }^{1}$
}

Reverse Asymmetric Warfare

Reis FRIEDE ${ }^{\bullet}$

Resumo: O presente artigo analisa a denominada Guerra Assimétrica Reversa, abordando os conceitos de Guerra Assimétrica e de Guerra Assimétrica Reversa e discorrendo, ainda, sobre os elementos característicos pontuais relativos à assimetria reversa, os eventos geopolíticos históricos ilustrativos dos fenômenos de assimetria básica e reversa, os efeitos sinergéticos da assimetria reversa, a anatomia fenomenológica da assimetria reversa, a realidade impositiva da assimetria reversa e os efeitos colaterais da assimetria reversa.

Palavras-chave: Guerra; Assimetria Reversa; Eventos Geopolíticos; Efeitos Colaterais.

Abstract: This article analyzes the so-called Reverse Asymmetric Warfare, approaching the concepts of Asymmetric Warfare and Reverse Asymmetric Warfare and also discussing on the characteristic elements related to specific reversed asymmetry, the geopolitical events that illustrate the historical phenomena of basic and reverse asymmetry, the synergistic effects of reversed asymmetry, the anatomy of the phenomenological reversed asymmetry, the imposing reality of reversed asymmetry and the side effects of reversed asymmetry.

Keywords: War; Reverse Asymmetry; Geopolitical Events; Side Effects.

O estudo relativo à denominada Guerra Assimétrica - e, mais recentemente, à moderna (e, para alguns, inovadora) concepção de Guerra Assimétrica Reversa -, reveste-se de especial importância, notadamente para o desiderato último da perfeita compreensão do fenômeno político alusivo aos Conflitos Bélicos, particularmente no século XXI.

Destarte, com o fim da chamada Confrontação Bipolar Indireta (típica do período da Guerra Fria (1947-91)), não há mais como interpretar os resultados políticos e militares, dos mais recentes embates bélicos, - através de uma necessária análise de maior profundidade, e com inafastável correção -, sem considerar a complexa fenomenologia da Assimetria Reversa.

\section{Conceitos de Guerra Assimétrica e de Guerra Assimétrica Reversa}

O Conceito clássico de Guerra Assimétrica, há muito conhecido, pode ser sintetizado como "todo e qualquer tipo de conflito bélico em que, - pelo menos em algum momento -, a superioridade militar (e, particularmente, tecnológica) de um dos contendores resta evidente no Campo de Batalha”.

\footnotetext{
- Desembargador Federal, Catedrático, ex-Membro do Ministério Público, Mestre e Doutor em Direito, ProfessorCoordenador da Escola de Pós-Graduação em Direito da UniverCidade e Professor-Coordenador dos Cursos de Graduação em Direito da UniverCidade - Campus Centro e autor de inúmeras obras jurídicas, dentre as quais "Ciência do Direito, Norma, Interpretação e Hermenêutica Jurídica", 4a edição, Forense Universitária, 2001, RJ (189 pp.) e "Vícios de Capacidade Subjetiva do Julgador: Do Impedimento e da Suspeição do Magistrado nos Processos Civil, Penal e Trabalhista", $3^{\text {a }}$ edição, Forense, 2001, RJ (469 pp.). E-mail: reisfriede@ hotmail.com
} 
Por outro prisma, a noção central de Guerra Assimétrica Reversa poderia ser traduzida como "todo e qualquer tipo de conflito bélico em que, - pelo menos em algum momento -, existe a efetiva limitação (ou, em termos mais precisos, autolimitação) do emprego da evidente superioridade militar (e, particularmente, tecnológica) no Campo de Batalha".

Desta feita, é a concepção estrutural de Assimetria Reversa (e sua perfeita compreensão), em flagrante oposição à concepção clássica de Assimetria Básica, que, em última análise, determinará a caracterização de uma autêntica revolução na sociologia do emprego do Poderio Militar, no presente e, em especial, durante todo o espaço-tempo relativo ao século XXI.

\section{Guerra Assimétrica e Guerra Revolucionária}

Não obstante o reiterado equívoco histórico em se associar o conceito de Guerra Assimétrica com a antiga noção de Guerra Revolucionária ou de Guerra Clássica, na modalidade de estratégia revolucionária, ou, ainda, em termos mais genéricos, de Guerra Irregular (em essência, conceito relativo à Natureza do Conflito), é cediço concluir que não se confundem as aludidas menções descritivas, sobretudo porque resta incorreto, em uma análise mais aprofundada do tema vertente, afirmar a caracterização analítica de Guerra Assimétrica com fundamento restritivamente na simples existência de alguma modalidade de guerrilha ou mesmo de outros elementos nãoconvencionais de confrontação que possam, eventualmente, traduzir, em situações pontuais ou mesmo de ampla concretude, no cenário específico de um determinado Teatro de Operações, algum viés de Assimetria Básica.

\section{Diagrama 1: Guerra Assimétrica Reversa x Guerras Revolucionária e Irregular}

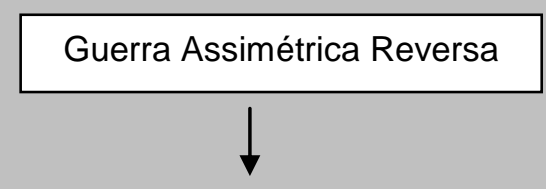

Todo e qualquer tipo de conflito bélico em que, - pelo menos em algum momento -, existe a efetiva limitação (ou, em termos mais precisos, autolimitação) do emprego da evidente superioridade militar (e, particularmente, tecnológica) no Campo de Batalha.

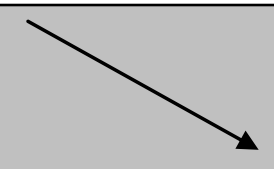

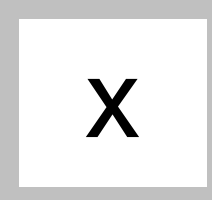

Guerra Revolucionária

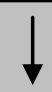

Todo e qualquer tipo de conflito bélico interno, não declarado e não reconhecido por organismos internacionais (e que não utiliza necessariamente a força militar, mas a subversão ideológica), e que possui uma Estratégia Popular, com Recursos de Ações Psicológicas e que tem por Finalidade a Mudança na Estrutura Política. 

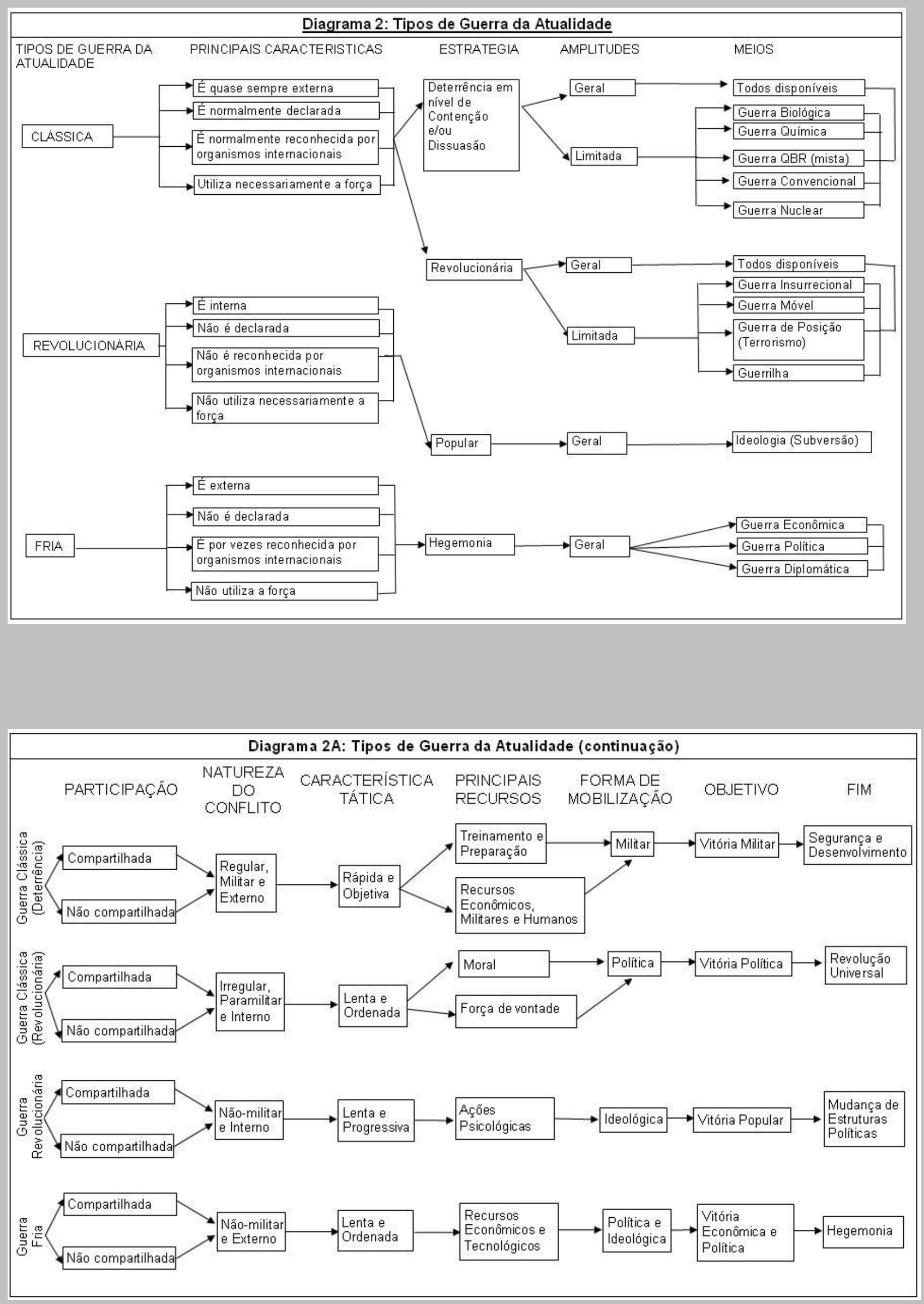
À luz de um necessário rigor acadêmico, resta dizer, a Assimetria, em essência, sequer poderia ser considerada uma genuína modalidade de Guerra, porquanto dentro de um contexto de uma linguagem dotada de maior seriedade técnica -, com necessário emprego de uma maior precisão vocabular -, a mesma coaduna restritivamente, por natural intuito vocacional, apenas e tãosomente com o modo exteriorizante pelo qual qualquer tipo de modalidade de Guerra é efetivamente conduzida, em um dado momento considerado ou mesmo no âmbito de sua total amplitude temporal, no Teatro de Operações em comento.

Muito embora, estatisticamente, seria até mesmo lícito afirmar que cerca de $90 \%$ (noventa por cento) das coloquialmente chamadas Guerras Irregulares são de natureza Assimétrica, tal fato probabilisticamente, por si só, a toda evidência, não possui o condão caracterizador, dotado de competência classificatória, capaz, em última instância, de identificar a modalidade do Conflito, precisando, em consequência, o tipo de Guerra, dentre as formas reconhecidamente consideradas pela Academia Militar.

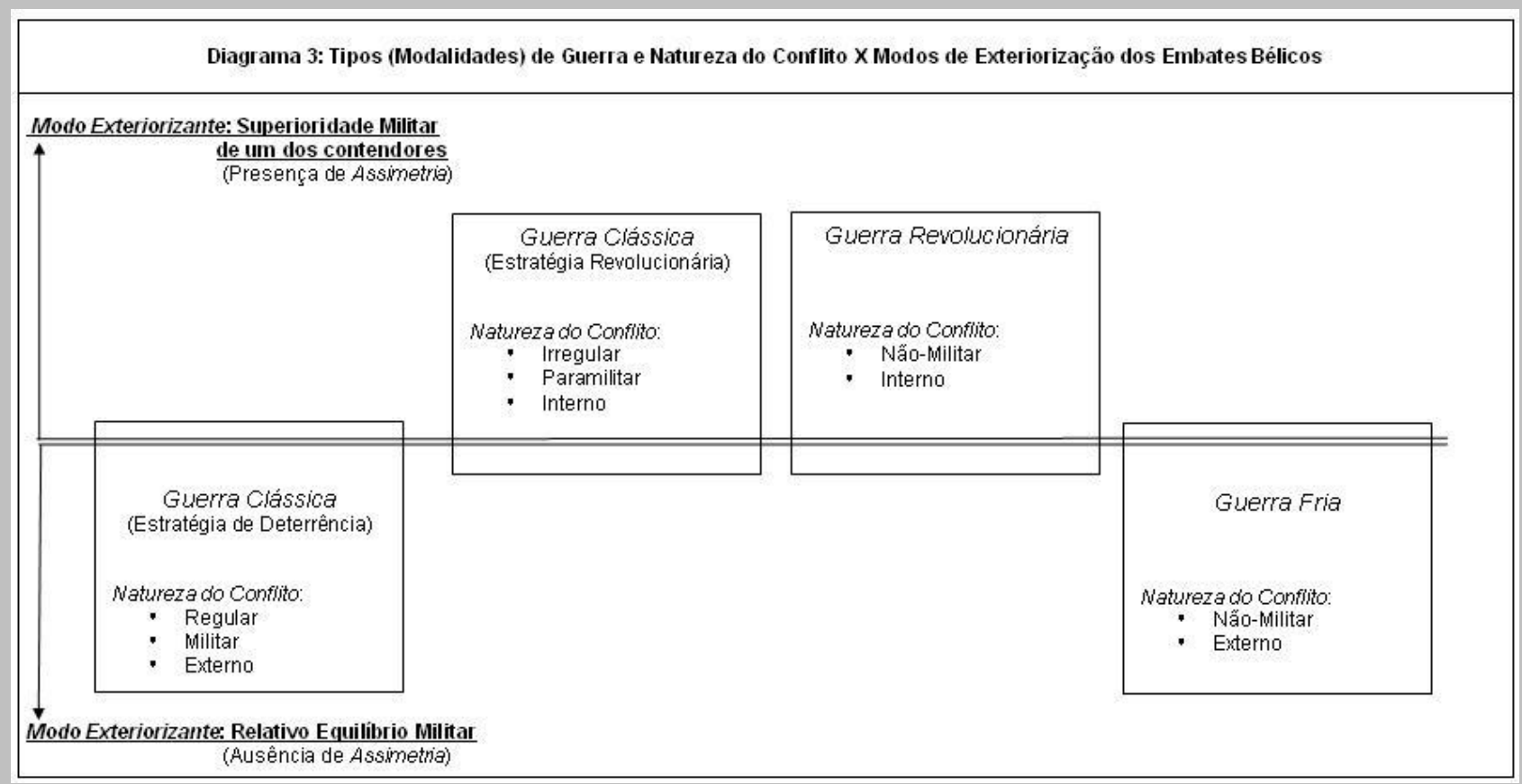

\section{Elementos Característicos Pontuais Relativos à Assimetria Reversa}

O fenômeno da Assimetria Reversa revela, fundamentalmente, em seu âmago, um verdadeiro conflito entre as concepções contemporâneas da civilização humana, como bem assim, a reconhecida dicotomia de valores associados à própria existência do gênero humano em seu atual estágio de desenvolvimento humanístico.

Por efeito consequente, o conceito estrutural (atual) de civilidade (incluindo as noções de moralidade e honradez), - defendido, particularmente, pela denominada Democracia Ocidental -, se opõe frontalmente ao conceito básico de barbárie (incluindo, neste, as ideias elementares de 
amoralidade e do próprio terror), supostamente partilhado pelos Totalitarismos Clássicos e, em especial, pelos denominados Totalitarismos Revolucionários, como o Islamismo Radical.

Sob esta ótica, resta afirmar que é o próprio confronto ideológico (em seu sentido amplo), - fundado em percepções conceituais tão diametralmente opostas (e, por esta razão, absolutamente inconciliáveis) -, que invalidam, por si só, toda e qualquer eventual vantagem político-militar derivada da nítida superioridade militar do protagonista democrático-ocidental no Campo de Batalha. Surge, em consequência, o epigrafado fenômeno da Assimetria Reversa -, mormente se considerarmos o imperioso respeito (autoimposto) às regras normativas de engajamento (particularmente restritivas do pleno emprego da capacidade militar e tecnológica disponível) que este protagonista se auto impõe em sinérgica oposição à absoluta ausência de regras clássicas de engajamento nos conflitos bélicos (e de outras naturezas assemelhadas) conduzidas pelos protagonistas de natureza transestatal, de índole nacional globalizante transcendente ${ }^{2}$. Vlembramos ainda, em necessária adição argumentativa, a própria preocupação central com a preservação da vida humana (objetividade realista), defendida pelas Democracias Ocidentais, versus a preocupação central com a preservação de valores (pseudo) espirituais (subjetividade concepcional), supostamente defendida pelos Entes Totalitários Revolucionários.

Diagrama 4: Elementos Característicos Pontuais Relativos à Assimetria Reversa

- Civilidade (Moralidade e Honradez) x Barbárie (Amoralidade e Terror)

- Existência de Regras (Normatividade) Clássicas de Engajamento (Restritivas)

x Ausência de Regras Clássicas de Engajamento

- Preocupação Central com a Preservação da Vida Humana (Objetividade Realista) x Preocupação Central com a Preservação dos Valores (Pseudo) Espirituais (Subjetividade Concepcional)

\section{Eventos Geopolíticos Históricos Ilustrativos dos Fenômenos de Assimetria Básica e Reversa}

Conforme já consignamos expressamente, o fenômeno da Assimetria Básica, umbilicalmente associado ao conceito clássico de Guerra Assimétrica, já era conhecido e, em grande medida, estudado, desde a antiguidade clássica. Todavia, foi somente com o advento da Guerra da Coreia, - mormente em sua segunda fase (inaugurada a partir da destituição do Gen. Douglas McArthur do supremo comando das operações, em 11 de abril de 1951) -, que o fenômeno paralelo e antagônico da Assimetria Reversa (e o consequente conceito de Guerra Assimétrica Reversa) foi amplamente 
reconhecido pelos mais importantes geoestrategistas da atualidade, ainda que através das mais diversas designações.

A exteriorização efetiva do mencionado fenômeno, em parte já registrada no presente ensaio, vale frisar mais uma vez, em necessário reforço analítico, caracteriza-se, sobremaneira, pela autolimitação (ainda que eventualmente parcial) do emprego da força militar, impedindo que a nítida e reconhecida superioridade bélica (massiva e/ou tecnológica) possa ser utilizada, em sua plena sinergia, com o diserato último de se conduzir à almejada vitória (política e militar) no campo de batalha.

Não é por outra razão que as Estratégias Políticas, relacionadas a praticamente todos os grandes embates bélicos, até o mencionado momento histórico -, o que, a toda evidência, inclui a própria Segunda Grande Guerra (1939-45) e a chamada primeira fase da Guerra da Coreia (1950/51) -, foram sempre pautadas pela "vitória a qualquer custo" (associada à concepção clássica de Guerra Total), sendo, portanto, desconhecido, - pelo menos no que concerne à aplicabilidade histórica -, a ideia central da "vitória limitada" (associada à concepção contemporânea de Guerra de Contenção) e suas derivações conceituais posteriores.

\section{Eventos Históricos Característicos da Fenomenologia da Assimetria Reversa}

Neste sentido, resta oportuno registrar que somente ficou perfeitamente caracterizado, no conflito coreano, o fenômeno da Assimetria Reversa quando, ainda que com ampla e reconhecida superioridade militar, o governo de Harry Truman (1945-53) - o mesmo que (frise-se) autorizou o lançamento das bombas atômicas sobre Hiroshima (6 de agosto de 1945) e Nagasaki (9 de agosto de 1945), recusou-se, terminantemente, a continuar a partilhar (direta ou indiretamente) das estratégias de vitória total (e a qualquer custo) do Gen. McArthur (destituído em 11 de abril de 1951). Tais estratégias incluíam, dentre outras propostas, o bloqueio continental da China, o substancial aumento dos efetivos, o emprego de tropas da China Nacionalista (Taiwan) e até mesmo a utilização de armas nucleares, com o fulcro último de reunificação forçada das duas Coréias, sob a égide político-ideológica do Ocidente.

Nos anos 60, durante o controvertido embate no Sudoeste da Ásia, conhecido genericamente como Guerra do Vietna $\tilde{a}^{3}$, de forma até mais contundente, restou, mais uma vez, muito bem caracterizado o fenômeno da Assimetria Reversa, notadamente quando se inaugurou, no âmbito da inovadora concepção de Guerra de Contenção, a estratégia do "gradualismo desencorajante" (Doutrina de McNamara). Essa, em última análise, simplesmente (e, de certa feita, de modo inédito) impediu a utilização inicial (e, mesmo posteriormente, de forma amplamente reconhecida, em todas as fases do conflito) da nítida superioridade militar estadunidense, particularmente, de seu poderio aeroespacial (o que inexoravelmente restou comprovado, em uma análise mais aprofundada ao 
final do conflito, através do inconteste sucesso das operações Linebacker I (abril a outubro de $1972)^{4}$ e, posteriormente, com mais ênfase, Linebacker II (18 a 30 de dezembro de 1972) ${ }^{5}$ ), eventos específicos em que muitas das restrições de emprego do poderio aeroespacial anteriormente presentes, sobretudo, na operação Rolling Thunder $^{6}$, não foram mais observadas, pelo menos, na mesma intensidade de outrora.

\section{Eventos Históricos Característicos da Fenomenologia da Assimetria Básica}

Em virtual contraposição à efetiva caracterização do fenômeno da Assimetria Reversa, - e em indispensável reforço analítico de suas reconhecidas consequências político-militares -, diversos outros episódios históricos demonstram claramente, por outro prisma, - e, em sentido diametralmente oposto -, o natural resultado da superioridade militar no campo de batalha, mormente quando empregado em sua inteireza, sem as autorestrições, de toda e qualquer natureza, que são inerentes ao mencionado fenômeno.

Por efeito, a denominada Assimetria Básica, registrou inconteste presença, em diversos momentos históricos, exteriorizando-se ora, excepcionalmente, como natural reação à própria

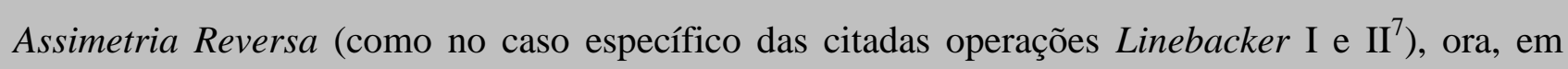
regra, como efetivo instrumento de estratégia política, como no caso do bombardeio a Dresden (fevereiro de 1945), - em que, empregando-se maciça superioridade aérea, os aliados, em um ataque ininterrupto de 14 horas de duração, destruíram completamente a mencionada cidade alemã, com um saldo de 35.000 mortos -, ou, mais recentemente, - e de forma até mais marcante -, no episódio conhecido como Segunda Guerra da Chechênia (1999-2009), que, em apertada síntese, resultou não só na inteira destruição da capital Grozny, como ainda num impressionante saldo de mortos de mais de 100.000 civis, representando $10 \%$ da população ${ }^{8}$.

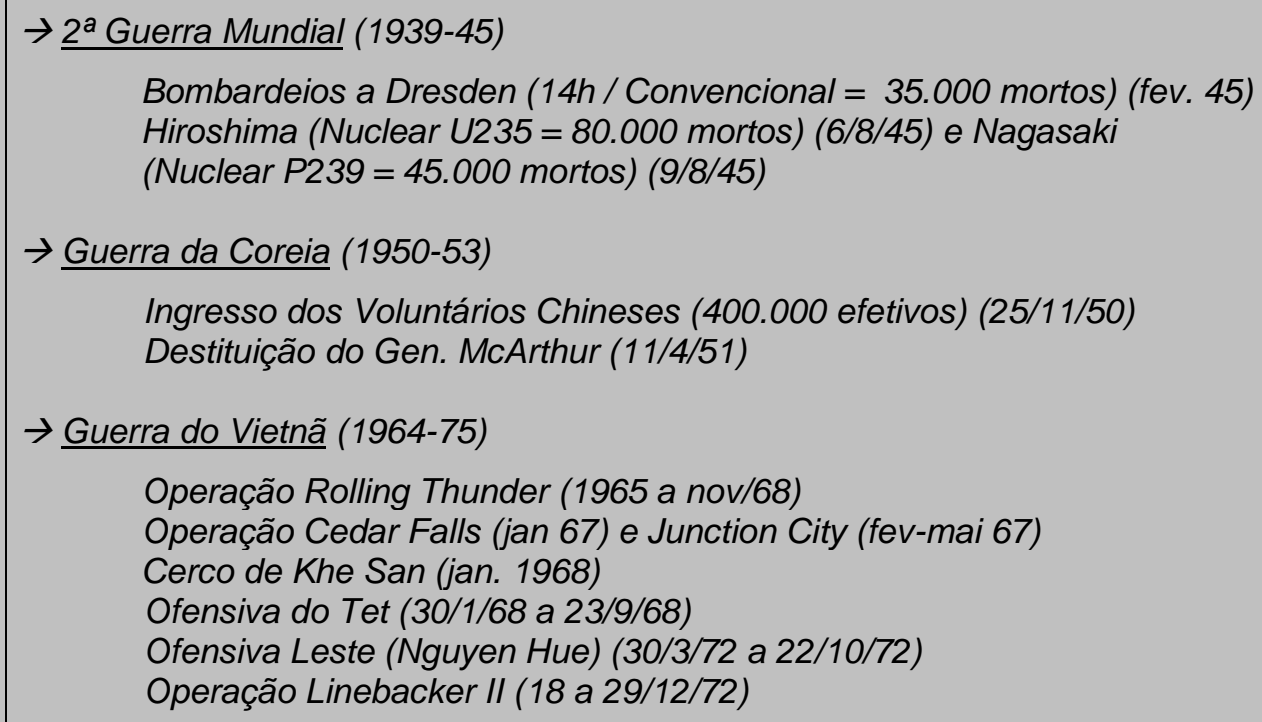




\section{Efeitos Sinergéticos da Assimetria Reversa}

No contexto deste prisma analítico, parece incontroverso os inequívocos efeitos sinergéticos da Assimetria Reversa, mormente quando o mencionado fenômeno se manifesta em sua absoluta plenitude.

Portanto, a questão fundamental que deve ser colocada em necessária análise não se restringe apenas aos eventuais resultados práticos produzidos pela presença do fenômeno epigrafado, mas, especialmente, se existe, na história recente, comprovados elementos analíticos que possam verdadeiramente desafiar a inconteste efetividade da Assimetria Reversa, em sua sinérgica exteriorização no Campo de Batalha.

Destarte, resta saber, no âmbito deste singelo debate, em necessário exercício analítico, se, por exemplo, mesmo com o amplo emprego de toda a moderníssima tecnologia militar estadunidense, - porém, com as inerentes restrições de utilização, no Teatro de Operações, características da denominada Assimetria Reversa -, os EUA lograriam obter, de forma objetiva, os mesmos resultados, de inconteste vitória político-militar, reconhecidamente alcançados pelos russos, durante o já mencionado episódio histórico conhecido como Segunda Guerra da Chechênia (1999-2009). Na ocasião, não obstante as perdas projetadas em 10.000 efetivos (incluindo forças locais pró-Moscou), a Rússia de Vladimir Putin, computando a completa destruição de Grozny, e o condenável extermínio de 100.000 chechenos (10\% da população total), incontestavelmente impôs, de forma inadjetivável (caracterizando, em virtual oposição analítica, uma autêntica Assimetria Básica), sua vontade política, debelando, por completo, as forças de oposição, em uma relativa repetição, ainda que em menor escala, do massacre de chechenos perpetrado por Stalin, entre 1942 e $1944^{9}$.

Ou mesmo, em outros termos de válido exercício de raciocínio comparativo, como foi possível ao governo de Saddam Hussein (1969-2003) instaurar uma autêntica ordem imperial, de controle praticamente absoluto, no âmbito político-social, de todo o território iraquiano, através da força das armas, contando, entretanto, com recursos militares muito mais limitados (e despendendo valores econômicos infinitas vezes inferior) comparativamente àqueles contabilizadamente empregados pelos EUA em seu amplo esforço de guerra (objetivando, em um segundo momento, a manutenção de uma ordem político-social mínima e, muitas vezes, em caráter visivelmente precário).

\section{Primazia Exteriorizante da Assimetria Reversa}

Neste diapasão, a par de toda a sorte de eventuais controvérsias que necessariamente norteiam o complexo tema em debate, é forçoso concluir que, mesmo com a plena utilização da mais avançada tecnologia militar (e, por derradeiro, com a obtenção de uma ampla superioridade bélica), 
esta, quando associada às inerentes restrições de seu emprego (autolimitação) no Campo de Batalha, simplesmente pode se traduzir em efeitos efetivos, de ordem prática, muito diferentes daqueles naturalmente esperados, frustrando expectativas por parte daqueles que simplesmente desconhecem o fenômeno sub examen e conduzindo, em última análise, a resultados comparativos muito aquém daqueles inexoravelmente obtidos através do emprego irrestrito da força militar (e paramilitar), mesmo quando estas forças oponentes (vale destacar em tom de sublime advertência), possam ser desprovidas (via de regra) de tecnologias modernas, em função exatamente da inafastável presença do predomínio pontual do fenômeno da Assimetria Reversa em sua plena efetividade, como muito bem revelou a história militar, com notável ênfase, a partir da segunda metade do século XX.

\section{Anatomia Fenomenológica da Assimetria Reversa}

Neste momento de necessária reflexão analítica, - a par de naturais perplexidades indagatórias -, uma afirmação conclusiva não pode deixar de ser, todavia, muito bem compreendida, em uma magistral clareza, qual seja: a denominada Assimetria Reversa não se constitui, per si, em um fenômeno isolado.

Muito pelo contrário, seu escopo de atuação, vale observar, encontra-se umbilicalmente associado à própria noção de Assimetria Básica, revelando-se, em certa medida, através de um genuíno "elemento exteriorizante" ínsito ao gênero maior das "assimetrias", relativas, por seu turno, às marcantes diferenças de postura militar (e, por consequência, de índole tecnológica) especialmente funcionais -, observáveis nos mais diferentes Teatro de Operações.

Por derradeiro, a anatomia da Assimetria Reversa somente pode ser entendida, em sua completude, quando associada necessariamente à sua imagem opositiva, representada, em sua mais enfática nitidez, por intermédio do fenômeno contrastante da Assimetria Básica ${ }^{10}$.

Não é por outra razão, portanto, que em alguns episódios históricos, de flagrante (e observável) onipotência da Assimetria Reversa, a Assimetria Básica também se fez presente, - com maior ou menor ênfase -, modificando, em alguns embates bélicos selecionados (muito embora não alterando o resultado final prognosticado, na maioria dos casos históricos), a própria tendência inicialmente verificada de previsível derrota militar (ou política).

Talvez um dos casos mais emblemáticos seja exatamente o conflito francês na Argélia em que, em sua primeira fase (1954-57), o exército regular francês, em conjunto com as forças policiais, utilizando notadamente táticas convencionais, não conseguiu conter a crescente insurreição na então Colônia. Após a introdução das forças especiais (paraquedistas franceses) em solo argelino (desta feita utilizando todo o seu potencial militar), ainda que pese ter havido o condenável uso de táticas de terror e tortura sistemática, os franceses, em uma segunda fase do 
conflito (1957-61), conseguiram, em pouco tempo, restabelecer a ordem político-social, impondo, através de efetiva exteriorização do fenômeno da Assimetria Básica-, a absoluta superioridade militar nas montanhas, como bem ainda na própria capital Argel ${ }^{11}$.

Apenas em função do verdadeiro escândalo que consternou toda a sociedade francesa com a ampla divulgação das táticas (condenadas por toda a comunidade internacional e rotuladas pela mesma como de índole "não civilizadas") empregadas pelos "lagartos" (denominação estereotipada através da qual ficaram conhecidos os paraquedistas franceses), é que o fenômeno paralelo da Assimetria Reversa mais uma vez se manifestou (desta feita, de forma verdadeiramente implacável). Ele impôs, em última análise, em apertada síntese, a derrota francesa e a consequente retirada gradual das tropas (e mesmo, em alguma medida, de cidadãos franceses) do solo argelino, viabilizando a plena independência da Argélia.

\section{Realidade Impositiva da Assimetria Reversa}

Desconhecer ou desconsiderar o fenômeno da Assimetria Reversa, por todas as razões já expostas, parece, hoje, destarte, um exercício hipotético simplesmente inimaginável, posto, também, que muitas das aparentes contradições detectadas nos Campos de Batalha (e em conflitos recentes, de modo geral) não poderiam ser logicamente explicadas (e, acima de tudo, compreendidas), - encerrando um estudo mais aprofundado do perceptível sucesso ou fracasso das intervenções militares no final do século XX e início do século XXI -, sem que fosse necessariamente levado em conta a própria sinergia que reveste a denominada Assimetria Reversa ${ }^{12}$.

De outro modo, como explicar, com alguma solidez argumentativa, os desastrosos resultados obtidos pelos EUA particularmente na Guerra do Vietnã, e mais recentemente, os resultados pífios da segunda intervenção estadunidense no Iraque, inaugurada em 2003, e da OTAN no Afeganistão, desde 2001, estas duas últimas, inclusive, já desconsideradas dos tão propalados efeitos relativos ao anterior ambiente internacional de confrontação bipolar indireta.

Portanto, o fenômeno da Assimetria Reversa, independentemente da vontade dos principais protagonistas no cenário internacional, revela-se como uma realidade que se impõe por si mesma, sendo certo que o mencionado fenômeno se constituirá na tônica fundamental, e no verdadeiro elemento plasmático irradiante, pertinente aos desafios estratégicos previstos para o século XXI.

\section{Efeitos Colaterais da Assimetria Reversa}

Além de todos os já descritos efeitos, relativos à exteriorização do fenômeno da Assimetria Reversa $^{13}$ (perceptíveis e historicamente comprovados) nos principais conflitos militares, cumpre ainda destacar a inafastável presença de autênticos "efeitos colaterais" (diretos e indiretos) 
associados ao fenômeno, detectáveis, ao longo da história militar recente, nos mais diversos Teatros de Operações.

Sob este espectro analítico, obrigatório reconhecer que, desde o primeiro embate geoestratégico da Guerra Fria, ilustrado pelo bloqueio de Berlim (1948), as tímidas respostas reativas norte-americanas vis-à-vis com a real capacidade militar disponível daquela Nação, em cada momento histórico do pós-guerra, ensejaram, como natural consequência, novos desafios geopolíticos, em que, de forma cada vez mais contundente, fixou-se, de modo bem destacado, um novo paradigma limitante do emprego da força militar, comumente designado por confrontação bipolar indireta, além de, igualmente, estabelecer a presença inafastável, ainda que de maneira inicialmente menos marcante (embora crescente), do fenômeno da Assimetria Reversa, ambas em suas respectivas vertentes colaterais.

Desta feita, resta lícito concluir que a Guerra da Coreia (1950-53) foi, em certo aspecto, uma consequência reflexa da ausência perceptível de uma reação mais enérgica ao Bloqueio de Berlim (1948), como bem assim, a Crise dos Mísseis em Cuba (1962), a Consolidação da Influência Soviética em Cuba (1962-85) e o início do Envolvimento Estadunidense no Vietnã (1961-65) podem ser, em grande medida, creditados a falta de uma resposta de John Kennedy à construção do Muro de Berlim (1961).

A própria Derrota no Vietnã (1975), neste sentido, teria sido grande incentivadora do Expansionismo Soviético na África (1975-79), da Queda do Regime do Xá do Irã (1979) (e autorizadora da humilhante invasão da Embaixada Estadunidense em Teerã (1979-80)) e da própria Crise da América Central (1979-82), do mesmo modo que a Derrota Francesa na Indochina (1954) e a Derrota Anglo-Francesa-Israelense em Suez (1956) teriam tido papel destacado na posterior Crise da Argélia (1957-61).

Mais marcante ainda, - para se referir à temática estratégica de notável atualidade -, os resultados da Desestabilização do Irã (EUA/1979) e da Derrota Soviética no Afeganistão (URSS/1979-89) que em conclusão absolutamente indiscutível, permitiram a cristalização do Totalitarismo Radical nascente e, por consequência, a derradeira expansão do Islamismo Radical.

Todos os eventos que, em necessário reforço conclusivo, se afirmaram como marcas indeléveis, exemplificadoras dos inexoráveis resultados da colateralidade dos efeitos dos fenômenos combinados da Confrontação Bipolar Indireta e da Assimetria Reversa e, mais recentemente, com o fim da Guerra Fria, apenas deste último.

Em virtual contraposição aos efeitos (diretos e colaterais) dos fenômenos mencionados, todavia, a própria história encarregou-se de registrar resultados completamente distintos quando, por diferentes razões, o protagonista estatal (ou transestatal) utilizou, em alguma medida, mesmo que pontualmente (no aspecto tempo-espaço) de efetiva Assimetria Básica, a exemplo dos episódios 
históricos da Retomada de Seul (1950) (em que ocorreu a perseguição sistemática e a consequente morte de milhares de colaboradores comunistas (1950-51)), da Ofensiva Francesa na Argélia (1957-61) (ocasião em que a determinação francesa, através do emprego de paraquedistas e de táticas não-convencionais, conduziu a uma inconteste vitória militar), da Ofensiva Comunista do Exército Regular do Vietnã do Norte (ENV), que, adicionados aos guerrilheiros vietcongs, logrou obter excepcional êxito (político) (situação em que se viabilizou uma impensável tortura sistemática em Huê com um saldo de 6.000 mortos (1968)), das Invasões Soviéticas na Hungria (1956) e na Tchecoslováquia (1968) (desenvolvidas sem qualquer reação local ou da Comunidade Internacional), destruição do Grupo Guerrilheiro Maoísta Sendero Luminoso no Peru (pelo controvertido governo Alberto Fujimori no final dos anos 90, não obstante algumas ações isoladas do grupo, após o término daquele governo; em 2002 - ataque a bomba a embaixada norte-americana e, em julho de 2003, sequestro de funcionários argentinos que trabalhavam no gasoduto de Ayacucho), além do episódio mais recente (e amplamente mencionado neste trabalho) da Segunda Ofensiva Russa na Chechênia (19992009), em que o exército russo impôs, em termos plenos (e indiscutíveis), a sua vontade política, como ainda da Operação Chumbo Fundido (conduzida por Israel, na Faixa de Gaza, em janeiro de 2009, em que morreram 1.387 palestinos, encerrando, em definitivo, o lançamento de foguetes contra o território israelense), da chamada "Guerra dos Cinco Dias" (no início de agosto de 2008, em que uma desproporcional força militar impôs uma "pax" russa na Geórgia) e da dura repressão desencadeada por Pequim, no início de julho de 2009, contra a etnia muçulmana uigur com um impressionante saldo de milhares de mortos.

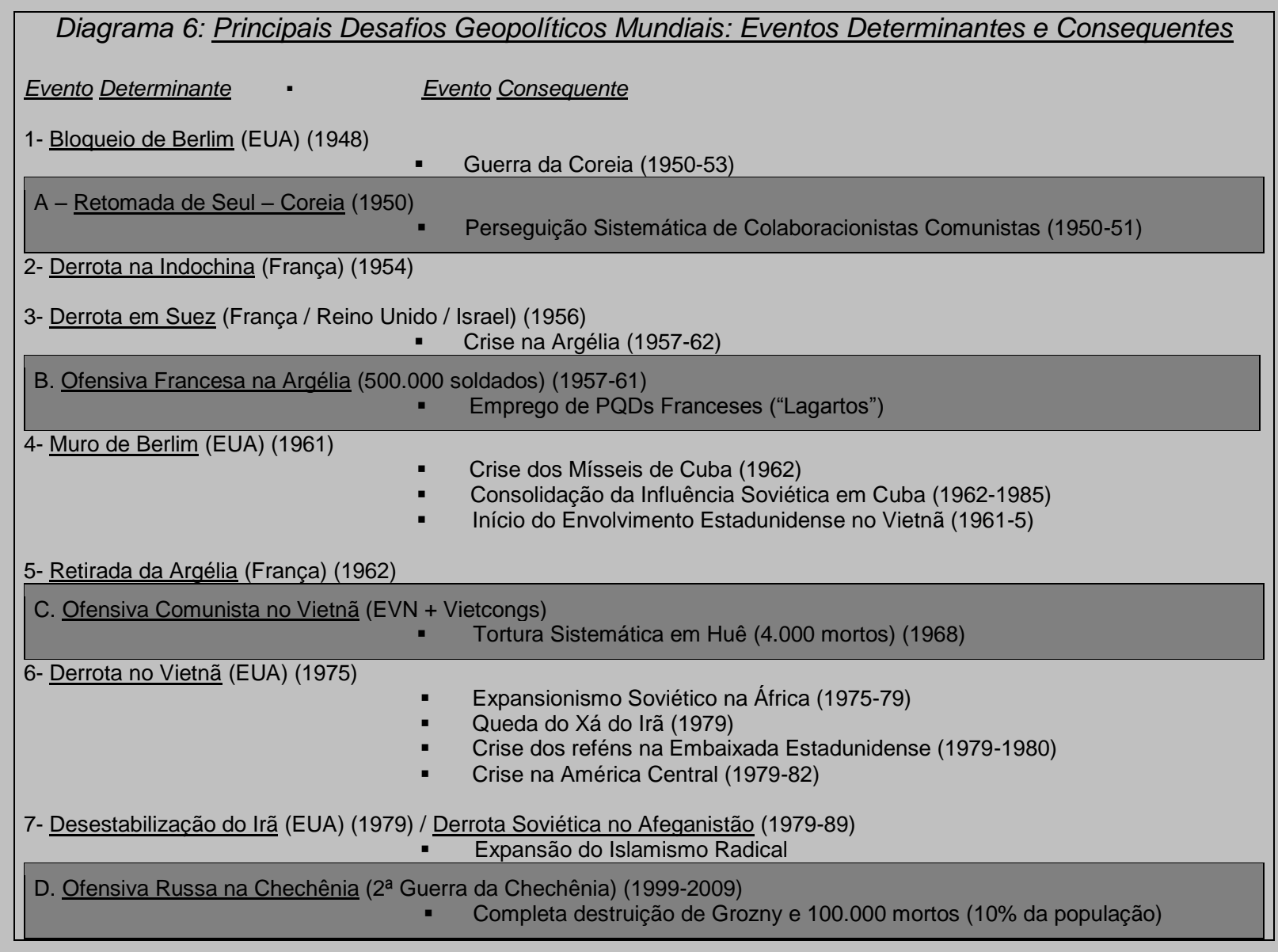




\section{Referências Bibliográficas:}

BRZEZINSKI, Zbigniew. O Grande Fracasso. Rio de Janeiro: Bibliex, 1990.

DALLEK, Robert. Nixon e Kissinger: Parceiros no Poder. Rio de Janeiro: Jorge Zahar Ed., 2009.

HUNTINGTON, Samuel P. O choque de civilizações e a recomposição da Ordem Mundial. Rio de Janeiro: Objetiva, 1998.

MIR, Luís. Guerra Civil: Estado e Trauma. São Paulo: Geração Editorial, 2004.

MORGENTHAU, Hans J. A Política entre as Nações. Brasília: Imprensa Oficial/UNB, 2003.

\section{NOTAS}

${ }^{1}$ Fragmentos de palestra proferida na Escola de Comando e Estado-Maior do Exército (ECEME), em 04 de junho de 2009, para os oficiais estagiários do Curso de Política, Estratégia e Alta Administração do Exército - CPEAEx; na Escola de Comando e Estado-Maior da Aeronáutica (ECEMAR), em 01 de outubro de 2009, para os oficiais estagiários do Curso de Política e Estratégia Aeroespaciais - CPEA e na Escola Superior de Guerra (ESG), em 18 de agosto de 2010, para os estagiários do Curso de Altos Estudos de Política e Estratégia - CAEPE.

${ }^{2}$ Resta oportuno consignar que a natureza transestatal do Totalitarismo Revolucionário, típico do Islamismo Radical, conceitualmente não se opõe à ideia de movimento nacional globalizante ínsito ao mesmo, na própria medida em que a noção mais primitiva de Nação engloba, com toda a certeza, as vinculações comuns de cunho religioso, ou mesmo pseudorreligioso.

${ }^{3} \mathrm{Na}$ verdade, o conflito na Indochina possui raízes históricas muito anteriores e bem mais complexas. Todavia, o maciço envolvimento norte-americano, em apoio ao governo do então Vietnã do Sul, somente ocorreu durante o governo John Kennedy (1960-63), com o envio de milhares de assessores militares e, de modo mais objetivo, com o início das operações de guerra (1965), durante a égide do governo Lyndon Johnson (1964-1968). Vale registrar, por oportuno, que, além dos EUA; os países da OTSA (SEATO), Austrália, Nova Zelândia, Tailândia, Filipinas e Coreia do Sul (esta contribuindo com aproximadamente 40.000 efetivos) enviaram tropas de combate para o Vietnã, retiradas em 1971. A OTAN (NATO) e outros aliados, incluindo o Brasil, recusaram-se a atender um pedido formal de envio de tropas.

${ }^{4}$ A operação Linebacker I (a que alguns autores entendem ser uma renomeação da operação de apoio tático e suporte Freedom Train (abril de 1972)) caracterizou-se como uma excepcional manobra (notadamente de interdição) que logrou cortar as linhas de suprimento do Vietnã do Norte, durante a chamada Ofensiva Leste (Nguyen Hue), conduzida entre 30 de abril e 22 de outubro de 1972, obrigando Hanói a retornar à mesa de negociações de paz.

5 A operação Linebacker II pode ser considerada como resultado direto de um ultimato à Hanói, de iniciativa do presidente Richard Nixon (imediatamente após o conhecimento do resultado de sua reeleição), quando aquele governo suspendeu unilateralmente as conversações de paz de Paris. Mais de 120 bombardeiros B-52 Stratofortress (número superior ao próprio quantitativo atual de aeronaves B-52H no inventário da USAF) em 700 missões noturnas, somadas a 650 ataques diurnos, realizados através de caças-bombardeiros F-105 Thunderchief e F-111, lançaram, durante 11 dias, cerca de 100.000 toneladas de bombas (do total de 170.000 toneladas lançadas na soma de ambas operações Linebacker I e II), obrigando o Vietnã do Norte não só a voltar à mesa de negociações, mas também a assinar um acordo de paz em que, dentre outras obrigações, determinou o repatriamento imediato de todos os prisioneiros de guerra norteamericanos.

${ }^{6}$ A denominada operação Rolling Thunder (1965 a novembro de 1968) caracterizou-se pelo uso limitado e gradual do Poder Aéreo Estadunidense (tese de McNamara), não logrando danificar as capacidades de guerra do Vietnã do Norte, em função, sobretudo, das inúmeras restrições a ataques a bases de caças MIG e sítios de artilharia antiaérea. Registre-se que o primeiro sítio de SAM foi localizado em abril de 1965 e o primeiro avião americano derrubado em julho de 1965. Vale consignar também que o total de aeronaves perdidas durante todo o conflito superou o quantitativo de 4.000 unidades.

${ }^{7}$ Oportuno registrar, - em necessário reforço aditivo às informações já consignadas anteriormente a respeito do tema que no início de dezembro de 1972 as conversações de Paris (acordadas em outubro de 1972) foram suspensas unilateralmente pelo Vietnã do Norte, criando uma situação política inaceitável para o então presidente Richard Nixon, reeleito em novembro de 1972 com a promessa de por fim à Guerra do Vietnã. Em 14/12/72 foi, portanto, conforme mencionamos anteriormente, dado um ultimato à Hanói exigindo o reinício das conversações em 72 horas. No mesmo dia, todos os portos norte-vietnamitas foram minados e, em 18/12/72, 123 bombardeiros B-52, partindo de 3 diferentes 
bases, entre as quais Guam (Andersen) e U-Tapao (Tailândia), iniciaram os bombardeios sobre Hanói, Haiphong e Thai Nguyen, acompanhados por 54 F-4 Phantom II (escoltas) 20 F-4 dotados de interferidores de radar: chaff, 10 F-105 Thunderchief (com mísseis anti-radar) e A-7 Corsair II, além de 5 EB-66 Destroyer e EA-6B Prowler, 2 EC-121H

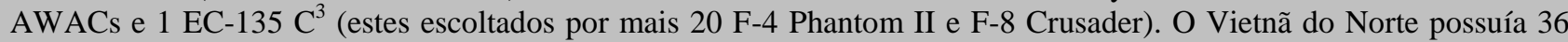
batalhões de SA-2 Guideline (mais 9 batalhões técnicos), suplementados por alguns batalhões SA-3 Goa, e milhares de SA-7 Grail (portáteis); além de 187 caças (71 operacionais), sendo 31 Mig-21 PFM (incorporados em 1969 com capacidade de interceptação noturna). Mais de 1.000 mísseis SAM foram disparados contra as aeronaves norteamericanas.

Principais ataques:

18-19/12/72: 129 B-52

20-21/12/72: 93 B-52

21-22/22-23/23-24/25-26: quantitativos reduzidos em face de acentuadas perdas de aeronaves (ensejando, em consequência, alteração de táticas)

26-27/12/72: $120 \mathrm{~B}-52$ (111 dos quais atingindo alvos)

27-28/12/72: 60 B-52

28-29/12/72: 60 B-52

29-30/12/72: 60 B-52

Um total de 700 missões noturnas (B-52) e 650 ataques diurnos (F-105 e F-111) foram realizados, até $7 \mathrm{~h}$ de 30/12/1972, com um total de 170.000 toneladas de bombas lançadas (incluindo as lançadas na Operação Linebacker I), obrigando o Vietnã do Norte a voltar às mesas de negociação em 2/1/1973 e obrigando o mesmo a repatriar todos os prisioneiros americanos, ainda no mesmo mês. Foram perdidos um total de 15 B-52 Stratofortress (2 interceptados por MIG-21), 2 F-111, 3 F-4 Phantom II, 2 A-7 Corsair II, 2 A-6 Intruder e 1 RA-5C Vigilante.

Para o Vietnã do Norte, a operação custou a vida de 1.624 civis/militares, obrigando a assinatura de acordos de paz, violados unilateralmente, mais tarde, sem qualquer tipo de reação internacional de maior monta, ou mesmo uma condenação mais severa da ONU.

O relativo fracasso da operação, segundo críticos, decorreu, sobretudo, pelo fato de ter permitido ao ENV manter suas posições no território sul-vietnamita e, sob o ponto de vista operacional, às restrições a eventuais danos à população civil, em significativa exteriorização fenomenológica da Assimetria Reversa.

Relatos de prisioneiros de guerra e documentos posteriormente divulgados, entretanto, mostraram que a operação Linebacker II destrui temporariamente a capacidade de guerra do Vietnã do Norte, quebrando seriamente o moral das tropas do ENV, demonstrando, neste sentido, a absoluta correção das críticas do Gen. Alexander Haig (que foi, durante a primeira administração de Nixon, Consultor Sênior Militar Adjunto para Assuntos de Segurança Nacional, promovido em outubro de 1969 a patente de general -, e, no segundo mandato, Vice-Chefe do Estado-Maior do Exército e Chefe de Estado da Casa Branca e, posteriormente, Comandante Europeu e Superior Aliado da OTAN (1974-79 - governos republicano Gerald Ford e democrata Jimmy Carter) e Secretário de Estado (primeiros 18 meses do governo Ronald Reagan)) para quem a interrupção nos bombardeios acima do paralelo 20, no dia 30 de dezembro de 1972, sem consultar Saigon e "sem forçar Hanói a evacuar suas tropas do Sul" consistiu em um "erro terrivel" (Robert Dallek; Nixon e Kissinger: Parceiros no Poder, Zahar, RJ 2009, p. 441), - ainda que a paranoia de Nixon (que havia, a menos de dois meses, obtido uma grandiosa vitória eleitoral sobre McGovern, - 60,7\% a 37,5\% -, vencendo em 49 dos 50 estados federados) o conduzisse a acreditar que se "fosse mantido o ataque aéreo, enfrentaria um impeachment" (ibidem, p. 442) -, o que acabou por transformar como verdadeira a denominada "paz falsa" (ibidem, p. 421), tanto alardeada pelo Presidente do Vietnã do Sul, Van Thieu, em conversas com Haig: "você já viu algum acordo de paz na história mundial no qual os invasores tivessem permissão para continuar no território que invadiram?" (ibidem, p. 429).

Muito embora os acontecimentos daquela época ainda possam ser classificados como um episódio, no mínimo, "nebuloso", a verdade é que, muito provavelmente, a primazia das ambições pessoais de Nixon (e seu relativo desprezo por Van Thieu) tenham sido o fator primordial para uma possível (e até hoje não comprovada) celebração de um "pacto oculto" (conhecido como "saída com honra") com Hanói (conduzido por Kissinger, - que apregoava um "intervalo decente" para a saída das tropas norte-americanas), o que bem explicaria a capitulação do Vietnã do Sul em 1975, não obstante Henry Kissinger ter garantido, em entrevista de 1972, que “(...) não há nenhum acordo escrito com o Vietnã do Norte sobre qualquer intervalo específico após o qual não nos preocuparíamos mais se eles invadissem e tomassem o controle do Vietnã do Sul" (ibidem, p.425).

${ }^{8}$ A $I^{a}$ Guerra da Chechênia iniciou-se em 1994 e terminou com os acordos de Khasavyunt (1996). Envolveu 40.000 efetivos russos, contabilizando 10.000 mortos (entre civis, militares e guerrilheiros). Com a instauração do regime islâmico por Aslan Maskhadov (1999), Vladimir Putin determinou uma nova invasão (2a Guerra da Chechênia) com o bombardeio completo a Grozny e sua inteira destruição, em resposta direta a explosão de prédios russos (300 mortos); a reação guerrilheira foi a tomada de um hospital (120 mortos) (1999), a invasão de um teatro em Moscou (150 mortos) (2003) e a invasão de uma Escola Pública Russa em Beslan (2 a 4/9/2004) (330 mortos), além de outros pequenos ataques terroristas, inclusive no metrô de Moscou. Em 16/04/2009, O Comitê Nacional Antiterrorista da Rússia (NKA) declarou a Chechênia "Zona Livre de Terrorismo", iniciando a retirada dos últimos 20.000 soldados russos, mantendo, outrossim, centenas de efetivos da FSB (KGB) e da polícia russa. 
${ }^{9}$ Vale lembrar que, em 1942, os chechenos se rebelaram contra o Regime Soviético, fazendo com que, em resposta, Stalin deportasse a totalidade dos chechenos (500.000) para o deserto da Ásia Central, ensejando a morte de aproximadamente 200.000 pessoas, entre homens, mulheres e crianças.

${ }^{10}$ Merece especial registro, - em contraposição à exteriorização da fenomenologia da Assimetria Reversa, no que concerne ao comportamento das Democracias Ocidentais no enfrentamento de desafios análogos -, a dura repressão, desencadeada por Pequim, no início de julho de 2009, contra a etnia muçulmana uigur que resultou, segundo denúncia do líder uigur Rebiya Kadeer (Globo, 30/7/09, p. 29), em 10.000 mortos ou desaparecidos (1.700 feridos e 1.600 presos,segundo o governo chinês) em apenas uma noite, durante os confrontos de forças policiais e militares chinesas em Urumqi, capital da Província de Xinjiang.

No mesmo sentido, igualmente merece menção a chamada "Guerra dos Cinco Dias", no início de agosto de 2008, em que uma incursão armada, por parte da Rússia, na Geórgia, debelou, com força flagrantemente desproporcional (em reconhecida imposição clássica de Assimetria Básica) a aventura georgiana na Ossétia do Sul, desincentivando, de forma sinérgica, qualquer tipo de nova empreitada político-militar naquela região contra os interesses russos.

Ainda, mesmo que com menor ênfase, também vale registrar, em necessária comparação analítica, as duas intervenções israelenses na Faixa de Gaza (2006, incluindo o sul do Líbano e 2009, restritivamente à Faixa de Gaza), cujo objetivo central de eliminar, por completo, os constantes ataques terroristas ao território israelense, com foguetes QASSAN e Katyushe (iranianos), somente foi definitivamente obtido na segunda empreitada ("Operação Chumbo Fundido"), onde o exército e a aviação judaicos foram utilizados com muito menos restrições de emprego (ocorreu um prévio bombardeio ininterrupto de oito dias com um saldo de mais de 420 mortos e 2.200 feridos) e com o nítido propósito de "aterrorizar a população civil", além de destruir a infraestrutura do Hamas, eliminando seus principais líderes, em nítida oposição a anterior (e observável) exteriorização da Assimetria Reversa (relativa a fracassada intervenção de 2006).

${ }^{11}$ Deve ser registrado que, à época, havia mais de um milhão de franceses em solo argelino, existindo, inclusive, um tradicional bairro francês na capital Argel.

${ }^{12}$ Não é por outra razão as recentes dificuldades que o Exército norte-americano tem observado (e se deparado) nos Conflitos do Iraque e, notadamente, do Afeganistão não obstante as raízes da fenomenologia da Assimetria Reversa transcenderem, em muito, as fronteiras temporais do século XXI (na verdade, ela remonta historicamente ao período do pós-segunda guerra mundial) e da própria natureza intrínseca dos conflitos, para, também, abranger grupos terroristas locais e ações de segurança interna.

Um contundente exemplo, foi a enorme dificuldade que a então República Federativa Alemã, durante o período compreendido entre 1968 e 1977, registrou para combater um pequeno grupo de estudantes anarquistas, - mal treinados e deficientemente armados (especialmente pela FPLP, na Jordânia) -, autodenominados inicialmente de "Facção Exército Vermelho" e, posteriormente, "Grupo Baader Meinhof", que simplesmente logrou aterrorizar uma aparentemente refém sociedade democrática alemã com assassinatos de juízes e policiais, além de diversos ataques terroristas com bombas e outros artefatos explosivos. Não obstante toda a relutância do governo alemão, à época, a verdade é que o conflito somente foi encerrado, em definitivo, com o sistemático assassinato de seus líderes, em 1977 , em uma prisão de Stuttgart, ocasião em que o Estado alemão, transcendendo as limitações típicas da Assimetria Reversa, - cumpre ressaltar -, fez valer, em última análise, a plenitude do poderio de seus instrumentos de repressão interna.

${ }^{13}$ A gênesis fenomenológica da Assimetria Reversa e, em termos mais amplos, da Guerra Assimétrica Reversa pode ser, em grande parte, creditada à vitória do ideário teórico defendido por George Kennan (e incorporado à Doutrina Truman em 1947, através das teses de confrontação indireta e sistema de alianças de defesa) em flagrante oposição às ideias de confrontação direta e guerra total de autoria de expressiva parcela da elite militar norte-americana, particularmente do Gen. MacArthur.

Artigo recebido em 09/2010. Aprovado em 10/2010. 